\title{
Transformational leadership and work motivation as predictors of organizational citizenship behavior
}

\author{
Tenang Mulyono ${ }^{1}$, Subiyanto ${ }^{2}$ \\ ${ }^{1 \& 2}$ Universitas Wijaya Putra Surabaya \\ tenang.kayu2@gmail.com
}

\begin{abstract}
The purpose of this study was to determine the direct effect of transformational leadership style (X1) and employee motivation (X2) on organizational citizenship behavior (Y). This study in CV.Putra Karya Agung. Distric of Gresik production unit employee. The number of sample who were taken as many as 92 employees from 120 member of the population by using the slovin method. This study using quantitative method. Data collection used through questionnaires using Likert scale and SPSS versi 21. The analysis method incudes mutiple linier regression.The result show that a significant of individual influenced between transformational leadership style (X1) to organizational citizenship behavior $(Y)$. While employee motivation (X2) do not dignificant of individual influenced to organizational citizenship behavior $(Y)$. And a significant of togeteher influenced between transformational leadership style (X1) and employee motivation (X2) to organizational citizenship behavior $(Y)$.
\end{abstract}

Keywords: Transformasional leadership style, employee motivation and organizational citizenship behavior.

\begin{abstract}
Abstrak: Tujuan penelitian ini adalah untuk menguji pengaruh langsung gaya kepemimpinan transformasional (X1) dan motivasi kerja (X2) terhadap organizational citizenship behavior.(Y). Penelitian ini dilakukan di CV Putra Karya Agung Kab. Gresik karyawan unit produksi . Jumlah sampel yang diambil sebanyak 92 orang karyawan dari 120 anggota populasi dengan menggunakan rumus Slovin. Penelitian ini menggunakan metode kuantitatif. Pengumpulan data dilakukan melalui penyebaran kuesioner dengan menggunakan skala Likert dan SPSS versi 21 . Teknik analisis yang digunakan adalah analisis regresi linear berganda.Hasil penelitian menunjukkan bahwa gaya kepemimpinan transformasional (X1) secara parsial berpengaruh positif dan signifikan terhadap organizational citizenship behavior (Y). Sedangkan motivasi kerja (X2) tidak berpengaruh secara parsial terhadap Organizational Citizenship Behavior (Y). Serta adanya pengaruh yang signifikan secara simultan antara gaya kepemimpinan transformasional (X1) dan motivasi kerja (X2) terhadap organizational citizenship behavior (Y)..
\end{abstract}

Kata Kunci: Transformasional leadership style, employee motivation and organizational citizenship behavior. 


\section{PENDAHULUAN}

Di era globalisasi perusahaan dituntut untuk bisa mengambil keputusan yang tepat dan mampu bersaing di lingkungan industri yang semakin ketat dan kompetitif, manajemen organisasi dalam perusahaan harus mampu dijalankan sesuai dengan fungsional perusahaan, Sumber daya manusia merupakan hal yang sangat penting sebagai faktor penggerak organisasi secara efektif untuk mencapai tujuan perusahaan.

Lee .dkk (2013) memaparkan bahwa perilaku ekstra peran atau yang lebih sering disebut dengan organizational citizenship behavior (OCB) memiliki peran penting dalam meningkatkan efektivitas, efisiensi, dan keuntungan bagi organisasi. Konsep dari OCB muncul sejak dua dekade yang telah lalu pada bidang perilaku organisasi dan hingga kini penelitian mengenai OCB terus berkembang. Seperti hal lain bahwa OCB sangat diperlukan pada perusahaan manufaktur apalagi pengelolahan bahan mentah menjadi setengah jadi, dari segi hal mengingatkan keselamatan kerja, teknik pelaksanaan kerja, pelaporan dan hal lain perlu adanya kepedulian antar sesama.

Menurut Northouse (2013) bahwa sebuah gaya kepemimpinan yang menekankan pada proses dimana orang terlibat dengan orang lain dan menciptakan suatu hubungan yang meningkatkan motivasi baik dalam diri pemimpin maupun pengikut. Pada dasarnya pemimpin yang memiliki gaya Transformasional memiliki visi kedepan dengan berorientasi pada perubahan yang diharapkan oleh perusahaan. Menurut Kartika Putri Susanto (2013)bahwa motivasi mendorong individu untuk menguatkan karakter dirinya serta individu terdorong memperlihatkan perilaku agar memperoleh dukungan sosial dan status. Individu terdorong untuk menyelesaikan pekerjaanya dengan harapan mencapai tujuan yang diharapkan perusahaanya, dengan hal itu individu akan memperlihatkan perilaku good citizenship. Motivasi kerja dikatakan berpengaruh terhadap OCB karyawan karena ketika karyawan termotivasi maka mampu membuat mereka merasa dihargai sehingga mampu memberikan pengaruh terhadap sikap mereka untuk menerima pekerjaan apapun dan melaksanakannya Soentoro, (2013).

Penelitian ini dilakukan pada CV. Putra Karya Agung yangbertempat di kabupaten gresik yang bergerak dalam bidang pengeolahan bahan kayu mentah menjadi bahan setengah jadi dan bahan jadi kualitas ekspor, memiliki tujuan dimana rasa solidaritas dan kepedulian terhadap sesama atau yang dikenal OCB menjadi faktor utama untuk saling bergotong-royong mencapai tujuan yang ditetapkan perusahaan serta mampu bekerja secara efisien dalam menjalankan misi perusahaan.

Sehubungan dengan hal diatas maka motivasi kerja sangat dibutuhkan dalam suatu perusahaan, karena dapat berpengaruh terhadap Organizational Citizenship Behavior dakam perusahaan, Selain itu juga pemimpin yang memiliki gaya transformasional diharapkan mampu untuk mempengaruhi anggotanya dan mencapai tujuan perusahaan Sehingga kemampuan pemimpin dalam memberikan motivasi akan sangat menentukan 
keberhasilan atau kegagalan dalam pencapian tujuan perusahaan. Menyadari betapa pentingnya motivasi dan gaya kepemimpinan transformasional dalam upaya menimbulkan OCB pada karyawan unit produksi.

Dalam rangka menimbulkan OCB (organizational citizenship behavior) pada karyawan unit produksi CV Putra Karya Agung, harus memberikan motivasi kerja dan kemampuan pemimpin kepada setiap karyawan. Karena dengan begitu dapat memberikan dorongan kepada karyawan untuk melakukan pekerjaan dengan maksimal dan memiliki rasa tanggung jawab terhadap pekerjaaan yang sedang dilaksanakan.

\section{TINJAUAN TEORITIS}

\section{Organizational Citizenship Behaviour (OCB)}

Organizational citizenship behavior merupakan perilaku dan sikap yang menguntungkan organisasi yang tidak bisa ditumbuhkan dengan basis kewajiban peran formal maupun dengan bentuk kontrak. Terkait dengan Robbins (2005) yang menyatakan bahwa organizational citizenship behavior sebagai perilaku individu atau perseorangan yang sukarela dan bukan bagiandari syarat formal pekerjaan, tetapi dapat meningkatkan fungsi efektif organisasi. Budihardjo, (2014) memaparkan OCB adalah suatu perilaku sukarela individu dalam hal ini karyawan yang tidak secara langsung berkaitan dalam sistem pengimbalan namun berkontribusi pada keefektifan organisasi.

Organizational citizenship behavior merupakan perilaku pekerja yang melebihi tugas formalnya dan memberikan kontribusi pada keefektifan organisasi Smith, dkk., (1983). Dengan demikian, apabila pekerja memiliki OCB yang tinggi maka akan diikuti pula dengan tingginya perilaku extra-role nya. Terlebih pada karyawan tetap, ketika mereka mampu bekerja lebih dari tugas formalnya, maka perusahaan lebih mudah dalam mengendalikan perilaku mereka, karena OCB merupakan perilaku yang tidak diharuskan oleh persyaratan peran atau deskripsi jabatan, bersifat bebas dan sukarela, sertamerupakan pilihan personal Podsakoff, dkk., (2000).

Organ, dkk., (2006) mengkategorikan faktor yang mempengaruhi OCB terdiri dari perbedaan individu, sikap kerja dan variabel kontekstual :

a) Perbedaan individu termasuk sifat yang stabil yang dimiliki individu,meliputi: kepribadian (misalnya kesadaran dan keramahan), kemampuan,pengalaman, pelatihan, pengetahuan, motivasi, kebutuhan, dan nilai individu.

b) Sikap kerja adalah emosi dan kognisi yang berdasarkan persepsi individu terhadap lingkungan kerja, meliputi: komitmen organisasi, persepsi kepemimpinan, dukungan organisasi, person organization fit, kepuasan kerja, psychological contract, persepsi keadilan dan keadilan organisasi.

c) Faktor-faktor kontekstual adalah pengaruh eksternal yang berasal dari pekerjaan, tim kerja, organisasi, atau lingkungan. Variabel kontekstual meliputi: karakteristik tugas, 
sikap pada pekerjaan, gaya kepemimpinan, karakteristik kelompok, budaya organisasi, profesionalisme, dan harapan peran sosial.

Organ, dkk., (2006) menjelaskan bahwa OCB dibangun dari lima aspek yang masing-masing bersifat unik yaitu :
a. altruism (perilaku menolong)
b. conscientiousness (kepatuhan)
c. sportmanship (sportifitas)
d. courtesy (kesopanan)
e. civic virtue (tanggung jawab sebagai anggota organisasi)..

\section{Gaya Kepemimpinan Transformasional}

Artana (2012) mendefinisikan pemimpin adalah orang yang membina dan menggerakkan seseorang tau kelompok orang lain agar mereka bersedia, komitmen, dan setia melaksanakan tugas dan tanggung jawabnya dalam mencapai tujuan perusahaan yang telah ditetapkan sebelumnya. Kepemimpinan (leadership) merupakan sifat atau karakter atau cara seseorang dalam upaya membina dan menggerakkan seseorang atau sekelompok orang lain agar mereka bersedia, berkomitmen, dan setia melaksanakan tugas dan tanggung jawabnnyadalam mencapai tujuan perusahaan yang telah ditetapkan sebelumnya.

Selanjutnya Maulizar (2012), memandang kepemimpinan sebagai sebuah proses mempengaruhi suatu aktifitas organisasi dalam upaya menetapkan dan mencapai tujuan. Sedangkan gaya kepemimpinan adalah pola prilaku dan strategi yang disukai dan sering diterapkan oleh seorang pemimpin Rivai, (2005). Humphyers (2012) menjelaskan kemampuan pemimpin transformasional mengubah sistem nilai bawahan demi mencapai tujuan diperoleh dengan mengembangkan salah satu atau seluruh faktor yang merupakan dimensi kepemimpinan transformasional, yaitu:

a) karisma (kemudian diubah menjadi pengaruh ideal (idealized influence)

b) inspirasi (inspirational motivation)

c) pengembangan intelektual (intellectual stimulation)

d) perhatian pribadi (individualized consideration)

Indikator dalam penelitian ini diambil dari penelitian yang dilakukan oleh Mariam (2009) yang telah diuji dan disesuaikan dengan dimensi yang dikemukakan oleh Bass dan Ruth. Dalam penelitiannya indikator kepemimpinan transformasional diukur dengan:
a) Meningkatkan Percaya diri
b) Implementasi Visi
c) Kreativitas
d) Nyaman bekerja dengan atasan
e) Meningkatkan Potensi Diri 
f) Memotivasi bawahan

g) Perhatian secara Pribadi

h) Mendorong Bawahan.

\section{Motivasi Kerja}

Robbins dan Judge, (2013) mengatakan bahwa ada suatu dorongan yang membuat seseorang untuk mencapai prestasinya secara maksimal. Dorongan itu berupa kebutuhan akan pencapaian prestasi, kebutuhan akan sosialisasi dan kebutuhan akan suatu kekuasaan atau pengaruh terhadap orang lain. Caroll dan Tosi (1977) menyebut hal ini sebagai motivasi, yaitu suatu keadaan mental internal dari suatu individu yang menyebabkan individu tersebut melakukan suatu aktivitas. Luthans (2006) mengungkapkan bahwa dalam konteks sistem, motivasi mencakup tiga elemen yang berinteraksi dan saling tergantung:

a) Kebutuhan, tercipta saat tidak adanya keseimbangan fisiologis atau psikologis.

b) Dorongan, merupakan tindakan yang berorientasi dan menghasilkan dayadorong dalam meraih insentif. Contohnya kebutuhan akan makanandanminuman, diterjemahkan sebagai dorongan lapar dan haus, serta kebutuhan berteman menjadi dorongan untuk berafiliasi.

c) Insentif, didefinisikan sebagai semua yang akan mengurangi sebuah kebutuhandan dorongan. Dengan demikian, memperoleh insentif akancenderungmemulihkan keseimbangan fisiologis atau psikologis dan akan mengurangi dorongan.

Thomas (2000) membahasan lebih lanjut mengenai aspek-aspek motivasi intrinsik menurutnya ada empat aspek motivasi intrinsik, yaitu:

a) Kompetensi atau competence, membuat orang-orang yang mempunyai keahlian,ketrampilan dan pelatihan merasa diperlukan, dan kompeten untuk lakukanpekerjaan yang dipercayakan kepada mereka.

b) Empati atau emphaty, dibutuhkan untuk memahami dengan berusahamelihat berbagai hal dari perspektif orang lain.

c) Otonomi atau autonomy, karyawan memilih sendiri cara dan metode untukmendapatkan hasil diinginkan, di tempat mereka turut ambil bagian pekerjaan.

d) Pemenuhan atau fulfillment, seseorang bekerja untuk suatu pemenuhan. Thomas (2000) mengemukakan bahwa motivasi kerja intrinsik dicapai ketika orang mengalamai perasaan-perasaan adanya pilihan, kompetensi, penuh arti, dan kemajuan.

\section{Research Terdahulu}

Atmaja dan Adnyani (2016) tentang Pengaruh Gaya Kepemimpinan Transformasional dan komitmen organisasional terhadap Organizational Citizenship Behavior (Studi karyawan Restoran The Sand Beach Bar \& Grill Seminyak). Hasil penelitian ini menyatakan bahwa adanya pengaruh signifikan antara gaya kepemimpinan 
transformasional dan komitmen organisasional terhadap Organizational Citizenship Behavior. Gunawan (2016) tentang Pemimpinan Transformasional Terhadap Organizational Citizenship Behavior (OCB) Pada PT First Marchinery Tradeco Cabang Surabaya. Hasil penelitian ini menyatakanbahwa gaya kepemimpinantransformasioanl berpengaruh signifikan terhadap variabel Organizational Citizenship Behavior. Haryono (2016) tentang pengaruh gaya kepemimpinan transformasional, human relation dan pemberdayaan karyawan terhadap organizational citizenship behavior dengan komitmen organisasi sebagai variabel intervening studi kasus Pada CV Karya Manunggal. Hasil penelitian ini menyatakan bahwa adanya signifikansi antara variabel gaya kepemimpinan transformational, human relations dan pemberdayaan karyawan terhadap komitmen organisasi. Studi selanjutnya yang dilakukan oleh Danendra dan Mujiati (2016) tentang motivasi, kompensasi dan komitmen organisasional terhadap organizational citizenship behavior (OCB). hasil penelitian ini menyatakan bahwa motivasi berpengaruh positif dan signifikan terhadap organizational citizenship behavior. dan yang terakhir studi yang dilakukan oleh Riantini dan Iriawan (2016) tentang pengaruh motivasi, disiplin dan kepuasan kerja terhadap organizational citizenship behavior tenaga Outsourching Di Dinas Pendapatan dan Pengelolaan Keuangan Kota Surabaya. Hasil penelitian ditemukan bahwa terdapat variabel Motivasi Kerja memiliki pengaruh secara parsial terhadap Organizational CitizenshipBehavior.

\section{METODE PENELITIAN}

Penelitian ini menggunakan jenis penelitian survei yang bersifat deskriptifeksploratif. Menurut Irawan (2011) disebutkan metode survei adalah "metode penelitian yang menggunakan kuisioner sebagai instrumen utama untuk mengumpulkan data". Pendekatan kuantitatif yang digunakan dalam penelitian ini dengan pertimbangan tersendiri. Alasan peneliti menggunakan pendekatan kuantitatif adalah dengan mempertimbangkan yang dilakukan oleh Arikunto (2013) tentang sifat umum peneliti kuantitatif, antara lain : (a) kejelasan unsur: tujuan, subjek, sumber data sudah mantap dan rinci sejak awal (b) dapat menggunakan sampel (c) kejelasan desain penelitian (d)analisis data dilakukan setelah semua data terkumpul.

\section{Populasi dan Teknik Pengambilan Sampel}

Menurut Arikunto (2013) populasi adalah keseluruhan dari subjek penelitian. Jadi yang dimaksud populasi adalah individu yang memiliki sifat yang sama walaupun prosentase kesamaan itu sedikit, atau dengan kata lain seluruh individu yang akan dijadikan sebagai obyek. Populasi dalam penelitian ini adalah seluruh karyawan khusus di unit produksi sebanyak 120 orang.Lokasi penelitian ini CV Putra Karya Agung Kabupaten Gresik yakni seluruh karyawan khusus di unit produksi. Arikunto (2013) berpendapat bahwa sampel adalah sebagian atau wakil populasi yang diteliti.Karyawan unit produksi yang akan dijadikan sasaran sampel penelitian menggunakan taraf kesalahan 5\%. Untuk menghitung penentuan jumlah sampel dari populasi tertentu yang 
dikembangkan, maka pengambilan sampel menggunakan rumus Slovin. Setelah dilakukan perhitungan maka yang akan dijadikan sebagai sampel dalam penelitian ini adalah sebanyak 92 karyawan. Dalam penelitian ini juga menggunakan uji validitas, uji reliabilitas, analisis deskriptif, analisis regresi linier berganda, uji $\mathrm{F}$ (simultan), uji t (parsial), koefisien determinasi

\section{HASIL DAN PEMBAHASAN}

CV. Putra Karya Agung merupakan sebuah industri manufaktur dibidang pengolahan kayu yang berlokasi di Jl.Mayjend Sungkono,dsn ngagorsari. Gresik. Pada tahun 2007 didirikan perusahaan baru di daerah gresik cabang dari PT Nankai Indonesia dari kota Palembang, CV Putra Karya Agung berdiri dari mitra perusahaan PT Nankai Indonesia dalam bentuk pengolahan bahan kayu, polywood, mebel dan dekorasi kayu. Mengingat perusahaan besar harus dikelola dengan baik dan benar, serta melihat rasa tanggung jawab karyawan untuk perusahaan. CV. Putra karya agung sendiri memiliki banyak karyawan 423 di semua unit kerja. Khusus untuk produksi ada 120 karyawan. CV Putra Karya Agung memiliki penilaian kinerja yang dikelola dengan baik dan jenjang karir yang jelas, sehingga karyawan mendapat motivasi tersendiri dalam bekerja. Aktivitas produksi yang ada di CV Putra Karya Agung adalah: Pembuatan desain dan model produk, Penyediaan bahan, Dokter kayu, Pemotongan kayu, Pembuatan lubang, Pembuatan sambungan, Penghalusan kayu, Proses pewarnaan cat dasar, Pewarnaan akhir, Pengontrolan, Packing.

\section{Karakteristik Responden}

Tabel 1. Karakteristik Responden Berdasarkan Usia, Jenis Kelamin, Pendidikan, dan

\begin{tabular}{lcr} 
& Masa Kerja & \\
\hline Usia (tahun) & Frekuensi & Prosentase (\%) \\
\hline$\leq 25$ Tahun & 10 & 11 \\
26-30 Tahun & 17 & 18,4 \\
31-35 Tahun & 28 & 30,4 \\
36-40 Tahun & 37 & 40,2 \\
$>40$ Tahun & 0 & 0 \\
Total & 92 & 100 \\
Jenis Kelamin & Responden & Prosentase $(\boldsymbol{\%})$ \\
Laki-Laki & 69 & 75 \\
Perempuan & 23 & 25 \\
Total & 92 & 100 \\
Pendidikan terakhir & Responden & 0 \\
SMP & 0 & 84 \\
SMA & 77 & 14 \\
D3 & 13 & 2 \\
S1/D-IV & 2 & 100 \\
Total & 92 & Prosentase \\
Masa Kerja & 0 & 0 \\
< Tahun & 48 & 52,1 \\
1 Tahun & 13 & 14,1 \\
2 Tahun & Responden \\
\hline \hline
\end{tabular}




\begin{tabular}{lcr}
\hline 3 Tahun & 9 & 9,7 \\
$\geq 4$ Tahun & 22 & 24,1 \\
Total & 92 & 100 \\
\hline
\end{tabular}

Diketahui bahwa mayoritas responden berusia 36-40 tahun dengan jumlah 37 responden. Jadi dapat diambil kesimpulan bahwa jumlah responden yang mengisi kuesioner mayoritas usia 36-40 tahun dengan prosentase sebanyak 40,2\%. Berdasarkan jenis kelamin diketahui bahwa mayoritas responden berjenis kelamin laki-laki dengan jumlah 69 responden, jadi dapat diambil kesimpulan bahwa jumlah responden yang mengisi kuesioner mayoritas berjenis kelamin laki-laki dengan prosentase sebanyak $69 \%$. Apabila dilihat di pendidikan, diketahui bahwa 77 responden telah menempuh pendidikan SMA, jadi dapat diambil kesimpulan bahwa jumlah responden yang mengisi kuesioner mayoritas dengan nilai prosentase paling tinggi telah menempuh pendidikan SMA dengan prosentase sebanyak 84\%. Sedangkan berdasarkan masa kerja diketahui bahwa 48 responden telah mempunyai masa kerja selama setahun, jadi dapat diambil kesimpulan bahwa jumlah responden yang mengisi kuesioner mayoritas sudah mempunyai masa kerja selama setahun dengan prosentase paling tertinggi yaitu sebanyak 52,1\%.

\section{Uji Validitas}

Uji validitas dimaksudkan untuk mengetahui apakah pernyataan dalam kuesioner cukup representatif. Uji validitas dilakukan dengan menggunakan analisis korelasi Pearson Product Moment pada masing-masing variabel yaitu kepemimpinan transformational (X1), motivasi kerja (X2), organizational citizenship behavior (Y1) dengan bantuan program SPSS 20.0. Sebuah data dinyatakan valid apabila koefisien korelasi pada setiap indikatornya $>0,30$. Berikut ini hasil uji validitas dari setiap variabel:

Tabel 2. uji validitas variabel gaya kepemimpinan $\left(X_{1}\right)$

\begin{tabular}{|c|c|c|}
\hline Pernyataan & Koefisien Korelasi & Keterangan \\
\hline $\mathrm{X} 1.1$ & $\overline{0,767}$ & Valid \\
\hline $\mathrm{X} 1.2$ & 0,675 & Valid \\
\hline $\mathrm{X} 1.3$ & 0,654 & Valid \\
\hline X1.4 & 0,591 & Valid \\
\hline X1.5 & 0,750 & Valid \\
\hline X1.6 & 0,407 & Valid \\
\hline X2.1 & 0,615 & Valid \\
\hline $\mathrm{X} 2.2$ & 0,741 & Valid \\
\hline X2.3 & 0,643 & Valid \\
\hline X2.4 & 0,763 & Valid \\
\hline X2.5 & 0,798 & Valid \\
\hline X2.6 & 0,736 & Valid \\
\hline Y.1 & 0,742 & Valid \\
\hline Y.2 & 0,593 & Valid \\
\hline Y.3 & 0,798 & Valid \\
\hline Y.4 & 0,631 & Valid \\
\hline Y.5 & 0,719 & Valid \\
\hline Y.6 & 0,416 & Valid \\
\hline
\end{tabular}


Dapat diketahui bahwa GK1, GK2, GK3, GK4, GK5, \& GK6, MK1, MK2, MK3, MK4, MK5, \& MK6, OCB1, OCB2, OCB3, OCB4, OCB5, \& OCB6 yang merupakan indikator variabel gaya kepemimpinan, Motivasi Kerja, dan OCB memiliki koefisien korelasi $>0,3$. Sehingga keenam indikator tersebut dinyatakan valid.

\section{Uji Reliabilitas}

Penggunaan pengujian reliabilitas oleh peneliti adalah untuk menilai konsistensi pada objek dan data, apakah instrumen yang digunakan beberapa kali untuk mengukur objek yang sama akan menghasilkan data yang sama. Kriteria keputusan uji reliabilitas jika nilai cronbach alpha> 0,60, maka instrumen tersebut bersifat reliabel. Berdasarkan hasil output uji reliabilitas (lampiran) pada tabel hasil reliabiltas tampak:

1. Reliabilitas gaya kepemimpinan (X1) dengan nilai cronbach alpha sebesar 0,7182 )

2. Reliabilitas Motivasi Kerja (X2) dengan nilai cronbach alpha sebesar 0,813 3)

3. Reliabilitas organizational citizenship behavior (Y) dengan nilai cronbach alpha sebesar 0,733 .

\section{Analisis Deskriptif}

Analisis dekriptif merupakan penelitian yang dilakukan untuk mengetahui nilai variabel independen dan variabel dependen. Berikut tabel skala interval:

Tabel 3. skala interval

\begin{tabular}{lccr}
\hline No & Interval & Pilihan & Skor \\
\hline 1 & $4,20<\mathrm{a} \leq 5,00$ & Sangat Tinggi & 5 \\
2 & $3,40<\mathrm{a} \leq 4,20$ & Tinggi & 4 \\
3 & $2,60<\mathrm{a} \leq 3,40$ & Sedang & 3 \\
4 & $1,80<\mathrm{a} \leq 2,60$ & Rendah & 2 \\
5 & $1,00<\mathrm{a} \leq 1,80$ & Sangat Rendah & 1 \\
\hline
\end{tabular}

Berdasarkan 92 jawaban dari responden kuesioner yang telah disebar kepada karyawan Unit Produksi CV Putra Karya Agung dapat diketahui bahwa responden menyetujui variabel gaya kepemimpinan. Ini dapat dibuktikan dengan nilai mean sebesar 4,12. Hal ini dapat diartikan bahwa persepsi yang dimiliki tentang gaya kepemimpinan pada karyawan unit produksi CV Putra Karya Agung memiliki kategori hasil yang tinggi dan dinyatakan baik. Kemudian untuk variabel komitmen organisasi, berdasarkan 75 jawaban dari responden kuesioner yang telah disebar kepada karyawan unit produksi CV Putra Karya Agung dapat diketahui bahwa responden menyetujui variabel motivasi kerja. Ini dapat dibuktikan dengan nilai mean sebesar 4,10. Hal ini dapat diartikan bahwa persepsi yang dimiliki tentang motivasi kerja pada karyawan unit produksi CV Putra Karya Agung memiliki kategori hasil yang tinggi dan dinyatakan baik.

Selanjutnya untuk variabel kinerja karyawan, berdasarkan 92 jawaban dari responden kuesioner yang telah disebar kepada karyawan unit produksi CV Putra Karya 
Agung dapat diketahui bahwa responden menyetujui variabel organizational citizenship behavior. Ini dapat dibuktikan dengan nilai mean sebesar 4,11. Hal ini dapat diartikan bahwa persepsi yang dimiliki tentang organizational citizenship behavior pada karyawan Unit Produksi CV Putra Karya Agung memiliki kategori hasil yang tinggi dan dinyatakan baik

\section{Analisis Regresi Linier Berganda}

Model telah memenuhi persyaratan analisis jalur meliputi data berskala interval, berdistribusi normal, pemenuhan asumsi normalitas, homokesdasitisitas, dan terbebas dari masalah multikolinieritas.

ANOVA $^{\mathrm{a}}$

\begin{tabular}{|l|r|r|r|r|r|}
\hline Model & Sum of Squares & \multicolumn{1}{|c|}{ Df } & Mean Square & F & \multicolumn{1}{c|}{ Sig. } \\
\hline Regression & 321,154 & 2 & 160,577 & 8,200 &, $001^{\mathrm{b}}$ \\
1 Residual & 1742,802 & 89 & 19,582 & & \\
Total & 2063,957 & 91 & & & \\
\hline
\end{tabular}

a. Dependent Variable: Y.OCB

b. Predictors: (Constant), X2.MK, X1.GK

Membuat persamaan struktural sesuai dengan kerangka konseptual, maka persamaan struktural yang dapat dibuat adalah:

$$
\mathrm{Y}=\mathrm{a}+\mathrm{b} 1 \mathrm{X} 1+\mathrm{b} 2 \mathrm{X} 2
$$

Berdasarkan hasil output analisis regresi linier yang telah di lakukan (lampiran) maka dapat digunakan untuk menyusun model persamaan regresi linier berganda sebagai berikut:

$$
\mathrm{Y}=\mathrm{a}+\mathrm{b} 1 \mathrm{X} 1+\mathrm{b} 2 \mathrm{X} 2 \mathrm{Y}=10,854+0,196 \mathrm{X} 1+0,283 \mathrm{X} 2
$$

Dari persamaan regresi tersebut dapat diketahui bahwa:

1. Koefisien a yang merupakan konstanta pada persamaan regresi menyatakan bahwa ketika variabel gaya kepemimpinan (X1) dan motivasi kerja (X2) bernilai konstan atau tetap maka nilai organizational citizenship behavior (Y) sebesar 10,854.

2. Koefisien regresi untuk variabel Gaya Kepemimpinan (X1) sebesar 0,196. Koefisien positif menunjukkan bahwa variabel Fasilitas Gaya Kepemimpinan mempunyai hubungan searah dengan organizational citizenship behavior (Y). Artinya apabila gaya kepemimpinan kerja meningkat sebesar satu satuan maka akan diikuti dengan meningkatnya Organizational citizenship behavior sebesar 0,196 dengan asumsi variabel motivasi kerja (X2) dalam keadaan konstan.

3. Koefisien regresi untuk variabel motivasi kerja (X2) sebesar 0,283. Koefisien positif menunjukkan bahwa variabel Fasilitas motivasi kerja mempunyai hubungan searah 
IMKA Implementasi Manajemen \& Kewirausahaan - April, Vol. 1, No. 1, 43-59, 2021

dengan organizational citizenship behavior (Y). Artinya apabila motivasi kerja meningkat sebesar satu satuan maka akan diikuti dengan meningkatnya Organizational citizenship behavior sebesar 0,249 dengan asumsi variabel Gaya Kepemimpinan ( (X1) dalam keadaan konstan.

\section{Uji F}

Uji F digunakan untuk mengetahui signifikan yang diberikan oleh variabel bebas yaitu variabel Gaya Kepemimpinan dan motivasi kerja terhadap variabel terikat, yaitu organizational citizenship behavior secara bersama-sama. Hasil pengujian secara simultan diperoleh sebagai berikut:

Dapat diketahui bahwa $\mathrm{F}$ hitung sebesar 8,200 didukung pula dengan tingkat signifikansi yang nilainya 0,00 lebih kecil dari 0,05 atau $5 \%$. Sehingga bisa disimpulkan bahwa kepemimpinan (X1) dan motivasi kerja (X2) secara simultan mempunyai pengaruh yang signifikan terhadap organizational citizenship behavior (Y) (H3 Diterima).

\section{Uji t (Parsial)}

Untuk mengetahui sejauh mana variabel bebas yang terdiri dari variabel bebas yaitu kepemimpinan (X1), dan motivasi kerja (X2) yang berpengaruh secara parsial atau sendiri-sendiri terhadap variabel organizational citizenship behavior (Y), maka digunakan uji t. Hasil pengujian secara parsial diperoleh bahwa masing-masing variabel X1 dan X2 berpengaruh langsung terhadap Y. Hal ini dapat dilihat dari probability (sig) kedua variabel $<0,05$. Pengujian signifikansi lebih lanjut diteruskan dengan pengujian individual melalui parameter statistik $\mathrm{t}$ yang menunjukkan kedua $\mathrm{t}$ hitung variabel memiliki nilai lebih besar dari t tabel. Sedangkan, $\mathrm{t}$ hitung $>\mathrm{t}$ tabel untuk variabel kepemimpinan mendapatkan nilai sebesar 7,450>1,901 dinyatakan bahwa secara langsung berpengaruh positif dan signifikan terhadap organizational citizenship behavior (H1 Diterima). Selain itu, nilai $\mathrm{t}$ hitung $>\mathrm{t}$ tabel untuk variabel motivasi kerja mendapatkan nilai sebesar 2,941 > 3,160 dinyatakan bahwa secara langsung berpengaruh positif dan signifikan terhadap kinerja karyawan. (H2 Diterima).

\section{Koefisien Determinasi}

Koefisien determinasi merupakan ukuran untuk mengetahui kesesuaian atau ketepatan antara nilai dugaan atau garis regresi dengan data sampel. Apabila nilai koefisien korelasi sudah diketahui, maka untuk mendapatkan koefisien determinasi dapat diperoleh dengan mengkuadratkannya.

Berdasarkan hasil spss dapat diketahui bahwa nilai R Square sebesar 0,156, maka dapat disimpulkan bahwa pengaruh variabel Kepemimpinan (X1) dan motivasi kerja (X2) 
secara bersama-sama terhadap variabel organizational citizenship behavior (Y) yaitu sebesar $15,6 \%$, sedangkan $84,4 \%$ dipengaruhi oleh variabel lain.

\section{PEMBAHASAN}

Deskripsi gaya kepemimpinan, motivasi kerja, dan organizational citizenship behavior karyawan Unit Produksi CV Putra Karya Agung gresik

Berdasarkan hasil kuisioner yang telah disebar dari semua variabel yaitu gaya kepemimpinan, motivasi kerja, dan organizational citizenship behavior diketahui ratarata nilai organizational citizenship behavior menunjukkan pernyataan yang cenderung memilih setuju. Hal ini dibuktikan dengan nilai angka rata-rata diatas 4. Untuk variabel gaya kepemimpinan yang mendapatkan nilai mean sebesar 4,12. Maka dapat dinyatakan bahwa persepsi tentang gaya kepemimpinan dalam karyawan Unit Produksi CV Putra Karya Agung dalam keadaan baik. Untuk variabel motivasi kerja yang mendapatkan nilai mean sebesar 4,10. Maka dapat dinyatakan bahwa persepsi tentang motivasi kerja dalam karyawan Unit Produksi CV Putra Karya Agung dalam keadaan baik. Untuk variabel organizational citizenship behavior yang mendapatkan nilai mean sebesar 4,11. Maka dapat dinyatakan bahwa persepsi tentang organizational citizenship behavior dalam karyawan Unit Produksi CV Putra Karya Agung dalam keadaan baik.

\section{Kepemimpinan tranformasional berpengaruh terhadap organizational citizenship behavior karyawan Unit Produksi CV Putra Karya Agung gresik}

Berdasarkan hasil analisis data diketahui bahwa gaya kepemimpinan (X1) memiliki pengaruh tapi tidak signifikan terhadap organizational citizenship behavior (Y). Hasil ini dibuktikan oleh nilai $\mathrm{t}$ hitung $>\mathrm{t}$ tabel serta nilai signifikansi diatas 0,05 . Sedangkan hubungan gaya kepemimpinan dan organizational citizenship behavior selalu searah dibuktikan dengan nilai $b$ unstandardized coefficient yang positif. Hal ini tidak sesuai dengan penelitian yang dilakukan I komang (2016) yang menyatakan gaya kepemimpinan berpengaruh terhadap organizational citizenship behavior.

\section{Motivasi kerja berpengaruh terhadap organizational citizenship behavior karyawan Unit Produksi CV Putra Karya Agung gresik}

Berdasarkan hasil analisis data diketahui bahwa motivasi kerja (X2) memiliki pengaruh terhadap organizational citizenship behavior (Y). Hasil ini dibuktikan oleh nilai $\mathrm{t}$ hitung $>\mathrm{t}$ tabel serta nilai signifikansi dibawah 0,05. Sedangkan hubungan motivasi kerja dan organizational citizenship behavior selalu searah dibuktikan dengan nilai B 
unstandardized coefficient yang positif. Hal ini sesuai dengan penelitian yang dilakukan Farahiyah (2016) yang menyatakan bahwa motivasi kerja berpengaruh secara signifikan terhadap organizational citizenship behavior.

\section{Gaya kepemimpinan dan motivasi kerja secara bersama-sama berpengaruh terhadap organizational citizenship behavior karyawan Unit Produksi CV Putra Karya Agung gresik.}

Berdasarkan hasil analisis regresi linier berganda, maka diketahui nilai koefisisen regresi dari masing-masing variabel bebas memiliki tanda positif. Hal ini menunjukkan hubungan yang searah antara variabel gaya kepemimpinan (X1) dan motivasi kerja (X2) terhadap Organizational citizenship behavior (Y). Nilai R Square sebesar 0,156 atau 15,6\% menunjukkan perubahan variable organizational citizenship behavior dipengaruhi dua variabel, yaitu gaya kepemimpinan dan motivasi kerja. Sedangkan sisanya sebesar $84,4 \%$ dipengaruhi oleh variabel lain, selain variabel gaya kepemimpinan (X1) dan motivasi kerja (X2) yang digunakan dalam penelitian ini.

Dari hasil uji F juga diketahui bahwa variabel bebas yaitu gaya kepemimpinan (X1) dan motivasi kerja (X2) memiliki pengaruh yang signifikan secara simultan terhadap organizational citizenship behavior (Y), ini di buktikan dengan nilai signifikansi sebesar 0,00 yang kurang dari 0,05 . Hal ini menunjukkan jika terjadi perubahan pada gaya kepemimpinan dan motivasi kerja akan menyebabkan perubahan pula terhadap Organizational citizenship behavior.

\section{KESIMPULAN DAN REKOMENDASI}

Berdasarkan hasil penelitian yang telah dilakukan, membuktikan bahwa semua indikator variabel disetujui oleh responden baik itu variabel gaya kepemimpinan, motivasi kerja, maupun organizational citizenship behavior. Semua variabel mendapatkan nilai yang tinggi, yang artinya bahwa Organizational citizenship behavior karyawan Unit Produksi CV Putra Karya Agung gresik dalam keadaan baik. Disisi yang lain, berdasarkan hasil penelitian yeng telah dilakukan, membuktikan bahwa secara parsial variabel gaya kepemimpinan tranformasional mempunyai pengaruh tapi tidak signifikan terhadap Organizational citizenship behavior karyawan Unit Produksi CV Putra Karya Agung gresik. Hal ini berarti membuktikan bahwa gaya kepemimpinan merupakan faktor yang tidak mempengaruhi bagus tidaknya Organizational citizenship behavior dalam melaksanakan tugasnya sehari-hari. Selain itu, berdasarkan hasil penelitian yang telah dilakukan, membuktikan bahwa secara parsial variabel motivasi kerja mempunyai pengaruh terhadap karyawan Unit Produksi CV Putra Karya Agung gresik. Hal ini dapat terbukti jika karyawan memiliki motivasi kerja dalam perusahaan tempat bekerjanya, maka nantinya akan menghasil organizational citizenship behavior yang baik sesuai dengan yang diharapkan oleh perusahaan. Sedangkan pengaruh secara simultan membuktikan bahwa variabel gaya pemimpinan dan motivasi kerja mempunyai 
pengaruh terhadap Organizational citizenship behavior karyawan Unit Produksi CV Putra Karya Agung gresik.

Rekomendasi yang dapat diberikan terhadap organisasi adalah sebaiknya bagi pihak CV.Putra Karya Agung tetap menerapkan Gaya Kepemimpinan Transformasional pada karyawan. Gaya kepemimpinan yang baik aka mampu menumbuhkan sifat Organizational citizenship behavior. Dengan catatan kepemimpinan unit produksi mampu melihat dengan pendekatan situasional. Disisi lain, sebaiknya juga mulai melakukan analisa atas tiap-tiap karyawan dari berbagai level dan melakukan identifikasi hal-hal yang berhubungan dengan motivasi kerja lebih lagi dilakukan sebuah trobosan dengan program yang memberikan motivasi dan stimulus, salah satunya berjalan dengan baiknya Talent pool dalam perusahaan menambah daya semangat sendiri bagi karyawan. Karena motivasi kerja yang baik dapat membantu perusahaan mencapai tujuan dan memperoleh, memelihara dan menjaga hubungan karyawan dengan baik, khusunya unit produksi. Selain itu, penelitian ini perlu dilanjutkan dengan penelitian yang lebih komprehensif, terutama terkait dengan penyempurnaan pembuatan angket yang lebih simple dan mudah dipahami. Hal ini untuk menghindari kejenuhan responden dalam mengisi angket.

\section{DAFTAR PUSTAKA}

Adniaty, D. 2014. Pengaruh Motivasi dan Disiplin Kerja Terhadap Kinerja Pegawai pada Kantor Dinas Pendapatan Daerah Provinsi Sumatera Utara UPT. Binjai. Medan:Universitas Sumatera Utara

Ahdiyana, Marita. 2013. Dimensi Organizational Citizenship Behavior dalam Kinerja Organisasi. hal: 1-10.

Prihatini, Ana., Warso, Moh Muker., \& Haryono, Andi Tri. (2016). Pengaruh gaya kepemimpinan transformasional, human relations, dan pemberdayaan karyawan terhadap organizational citizenship behavior dengan komitmen organisasi sebagai variabel intervening.

Antonio, Nio Erick \& Sutanto, Eddy M. (2014). Pengaruh Motivasi Dan Kepuasan Kerja Karyawanterhadap Organizational Citizenship Behavior Di Cv Supratex. Jurnal Mahasiswa Manajemen Bisnis 2.

Arikunto, Suharsimi. 2013. Prosedur Penelitian, Suatu Pendekatan Praktis. Jakarta : Penerbit Rineka Cipta.

Artana, I Wayan Arta. 2012. "Pengaruh Kepemimpinan, Kompensasi, dan Lingkungan Kerja Terhadap Kinerja Karyawan Studi Kasus di Maya Ubud Resort \& Spa" dalam Jurnal Manajemen, Strategi Bisnis, dan Kewirausahaan Volume 2 No.1 (hlm.66).

Budihardjo, A. 2014. "Mengenal Organizational Citizenship Behavior (OCB). Forum Manajemen Prasetiya Mulya Tahun ke-XVIII" Volume No. 82.

Budiyanto. 2013. "Pengembangan Kinerja Organisasi Publik (Pemerintah) dengan Pendekatan Organizational Citizenship Behavior (OCB)"dalam Orasi Ilmiah pada Dies Natalis Ke-41 Tahun Sekolah Tinggi Ilmu Ekonomi Indonesia (STIESIA). Surabaya : Universitas STIESIA. 
Carrol, Stephen., J, Henry L \& Tosi. 1997. Organizational Behavior. Illinois: ST. Clair Press.

Setyowati, Dwi. 2011. "Pengaruh Kompensasi, Motivasi Kerja dan Lingkungan Kerja terhadap Prestasi Kerja Guru Sekolah Dasar Negeri se-Gugus Dwarawati Kecamatan Banyumanik Semarang".

Darmawan, Didit. 2013. Prinsip-Prinsip Perilaku Organisasi. PT. Temprima Media Grafika.

E-Jurnal Manajemen Unud, Vol. 5, No. 11, 2016: 7225-7251.

Farahiyah, Eki Riantini \& Iriawan, Sandra. 2016. Pengaruh Motivasi, Disiplin dan Kepuasan Kerja Terhadap Organizational Citizenship Behavior TenagaOutsourching di Dinas Pendapatan dan Pengelolaan Keuangan Kota Surabaya.

Faruk, Omer. 2013. "Relationship Between The Facets of Job Satisfaction and The Dimensional of Organizational Citizenship Behavior". The Journal of Faculty of Economics and Administrative Sciences, 18 (1), pp: 243-269.

Ghozali, I. 2011. "Aplikasi Analisis Multivariate Dengan Program IBM SPSS 19. Badan Penerbit Universitas Diponegoro". Semarang.

Hadi. 2009. Teori Portofolio dan Analisis Investasi . Bandung; Alfabeta.

Humphrey,. 2012. "Transformational Leadership and Organizational Citizenship Behaviors: The Role of Organizational Identification”. The PsychologistManager Journal, 15 (1), pp: 247-268.

Ibrahim, M. A., and Aslinda. 2014. The effect of motivation on organizational citizenship behavior (OCB) at Telkom Indonesia in Makassar. International Journal of Administrative Science \& Organization. 21 (2) : 114-120.

I Komang, Adi Wira Atmaja \& Adnyani, Gst. Ayu Dewi. 2016. Pengaruh Gaya Kepemimpinan Transformasional dan Komitmen Organisasional Terhadap Organizational Citizenship Behavior.

Intan, Ike. 2017. 'Pengaruh Gaya Kepemimpinan Transformasional dan Kompensasi Terhadap Kinerja Karyawan UD. Aghnia Joyo Collection',

Irawan. 2011. Sistem Informasi Manajemen, Palembang; Maxicom

Kencanawati, A.A.M. 2014. "Gaya Kepemimpinan, Komitmen Organisasi dan Kepuasan Kerja memengaruhi Organizational Citizenship Behavior pada PT. (BPR) Cahaya Bina Putra Kerobokan Badung" dalam Jurnal Manajemen dan Kewirausahaan, 10(1): h: 44-45.

Kresnandito, Andika P., dan Fajrianthi. 2012. Pengaruh Persepsi Kepemimpinan Transformasional terhadap Perilaku Inovatif Penyiar Radio. Jurnal Psikologi Industri dan Organisasi, 1(2): h: 78-85.

Lamidi. 2008. "Pengaruh Kepemimpinan Transformasional Terhadap Organizational Citizenship Behavior: Dengan Variabel Intervining Komitmen Organisasional" dalam Jurnal Ekonomi dan Kewirausahaan Volume 8, no. 1 (Hlm. 25-37).

Lee, U.H, Hye Kyoung Kim and Young Hyung Kim. (2013). Determinants of Organizational Citizenship Behavior and Its Outcomes. Global Business and Management Research: An International Journal. Vol. 5, No. 1, 2013 pp. 54-65

Luthans, F. 2006. Perilaku Organisasi, Edisi Sepuluh. Yogyakarta: Penebit Andi.

Mariam, Rani. 2009. "Pengaruh Gaya Kepemimpinan dan Budaya Organisasi Terhadap Kinerja Karyawan Melalui Kepuasan Kerja Karyawan Sebagai Variabel Intervening". Tesis. Semarang; Universitas Diponegoro. 
Maulizar, Said Musnadi dan Mukhlis Yunus. (2012). Pengaruh Kepemimpinan Transaksional dan Transformasional terhadap Kinerja Karyawan Bank Syariah Mandiri Cabang Banda. Jurnal Manajemen Volume 1, Agustus 2012 (ISSN 2302-0199), hal 61.

Moghimi dan Firozabad, 2013, The Mediating Effects of Psychological Empowerment and Job Satisfaction in the Relationship between Transformational Leadership and Organizational Citizenship Behavior, Journal of Basic and Applied, Vol. 3,No.5.

Northouse, Peter G. 2013. Teori dan Praktik Kepemimpinan. Edisi Keenam. Jakarta: Permata Putri.

Novliadi, F. 2007. Organizational Citizen Behavior Karyawan Ditinjau dari Persepsi Terhadap Kualitas Interaksi Atasan-Bawahan dan Persepsi Terhadap Dukungan Orgnisasional, USU Repository.

Organ, D. W., Podsakof, P. M., and Mackenzie, S. B. (2006). Organizational citizenship behavior: Its nature, antecedents, and consequences. California: Sage Publication.

Podsakoff, P. M., and Mackenzie, S. B. 2000. Organizational citizenship behavior and sales unit effectiveness. Journal of Marketing Research, 31(3), 351-363.

Rahmayanti, Febriana, dan Dewi. 2014. Faktor-Faktor yang Mempengaruhi Organizational Citizenship Behavior (OCB). Jurnal Ecopsy Vol 1 No 3.

Rivai, V. dan Basri, A. 2005. Performance Appraisal. Jakarta: PT. Raja Grafindo Persada.

Robbins, S. P. and Judge, M . 2013. Organizational Behavior. New Jersey: Prentice Hall

Rochmanasari, D. 2013. Analisis Pengaruh Stres Kerja dan Gaya Kepemimpinan terhadap Kinerja Pegawai Perusahaan daerah Bank Perkreditan Rakyat BKK Kabupaten Demak. Fakultas Ekonomika dan Bisnis Universitas Dipenogoro (tidak diterbitkan).

Rudi Gunawan (2006) pengaruh kepemimpinan Transformasional terhadap Organizational Citizenship Behavior (OCB) Pada PT first marchinery Tradeco Cabang Surabaya

Sardjono, S., Huseini, M., Rahardjo, K., Arifin, Z. 2014. The Effect of Transformational Leadership, Superior-Subordinate Relationship, Job Satisfaction and Willing Cooperation Towards Organizational Citizenship Behaviour and Employee Performance. EuropeanJournal of Business and Management. Vol. 6, No.25, 2014.

Setiawan, N., 2010. Penentuan Ukuran Sampel Memakai Rumus Slovin dan Tabel Krejcie-Morgan: Telaah Konsep dan Aplikasi. In: Jatinangor: Universitas Pandjajaran, pp. 5-6.

Smith, C.A., Organ,D W., and Near,J.P (1983).Organizational Citizenship Behavior : It's Nature and Antecedents journal of applied psychology, Vol 68(4): 653-663

Sugiyono. 2013. Metode Penelitian Bisnis. Cetakan ke-17. Bandung: Alfabeta.

Soentoro, D. P. 2013. Pengaruh Motivasi Kerja, Kepemimpinan, Lingkungan Kerja Terhadap Organizational Citizenship Behavior Dan Kepuasan Kerja Di PT Sucofindo Surabaya

Supriyanto, A. S. \& Machfudz, M., 2010. Metodologi Riset Manajemen Sumberdaya Manusia. Malang: UIN Maliki Press.

Sutanto, Eddy M. dan Tania, Anastasia. (2013). Pengaruh Motivasi Kerja dan Kepuasan Kerja terhadap Komitmen Organisasional Karyawan PT. Dai Knife di Surabaya. AGORA, Jurnal Mahasiswa Manajemen Bisnis 1 (3) 
Taruno, F.X. Soewarto, C., Thoyib, A., Zain, D., Mintarti, R. 2011.Pengaruh Gaya Kepemimpinan terhadapKinerja Dosen dengan Kepuasan Kerja dan MotivasiKerja sebagai Mediator (Studi pada Perguruan Tinggi Swasta di Jayapura) Jurnal Aplikasi Manajemen,Volume 10, Nomor 3, halaman 495-509.

Thaha, R. 2012. Penataan Kelembagaan PemerintahanDaerah, Repository Jurnal Unhas. Hal 38-60.

Thomas, K. W. 2000. Intrinsic Motivation at Work: Building Energy and Commitment. San Francisco, CA: Berrett-Koehler Publishers, Inc.

Wijarnoko. 2014. Pengaruh Kepemimpinan Transformasional dan Motivasi kerja terhadap Kinerja Agen pada Agen PT. Asuransi Jiwasraya (Persero) Yogyakarta. Skripsi Menejemen, Oktober 2014, Universitas Negeri Yogyakarta

Yaghoubipoor, A., Tee, O.P., Ahmed, E.M. 2013. Impact ofthe relationship between transformational and traditionalleadership styles on Iran's automobile industryjob satisfaction. World Journal of Entrepreneurship, Management and Sustainable Development.Vol. 9 No. 1, 2013 pp.14-27.

Yuwono, S., Susanto, K. P. \& Ferdiana, V., 2014. Hubungan antara Motivasi dan Kepuasan Kerja dengan Organizational Citizenship Behavior (OCB). Research Methods And Organizational Studies, pp. 444-451.

Zopiatis., Constanti, A., and Panayiotis C. 2012. Extraversion, Openness, and Conscientiousness The Route To Transformasional Leadership In The Hotel Industry. Leadership and Organization Development Journal, 33(1): pp: 86-91. 